\title{
The Influence of Tacit Knowledge on the Behaviour of College Students
}

\section{Jana Matošková, Martina Polčáková, Michaela Baňařová, Eliška Sobotková, Martin Jurásek, Terézia Růžičková}

\begin{abstract}
Tacit knowledge is one of the factors that influence the success of studying at colleges. The aim of the study overview is to clarify the principle of the mentioned phenomenon. Students owning tacit knowledge are often unaware of it, although tacit knowledge influences their actions. Tacit knowledge impacts also on their assumptions, beliefs and feelings. The ability to form tacit knowledge quickly and to develop it is one of the demonstrations of so-called practical intelligence. Students who have tacit knowledge are able to adapt their behaviour to an academic setting and so play a successful role. They also prepare themselves for their position in future work and to achieve their life aims successfully. Moulding of tacit knowledge can be facilitated by the setting created by teachers but the key role in this process belongs to the students themselves.
\end{abstract}

Key words: Tacit Knowledge, Academic Tacit Knowledge, Behaviour of Successful Students, Tacit Knowledge Moulding.

\section{Introduction}

During the period 2001 to 2010 the number of college students in the Czech Republic has increased from 204,000 to almost 400,000 (ANON. 2012). In the academic year $2012 / 2013,72,554$ students were placed into studies at colleges for the first time 
(ANON. 2013). However, not all of them will finish their studies successfully. From the report of Kleňhová and Vojtěch $(2011$, p. 7) results show that approximately $15 \%$ of students leave college early. Most of the drop out students give up in the second year of their studies (Kleňhová and Vojtěch 2011, p. 7). This fact is not very optimistic because as Jirotková (2010) says a successfully completed level of education has quite a significant effect on a student's success in the labour market.

Whether a student finishes the college successfully or not is influenced by many factors - who the students are, their predispositions for studying, their commitment, health and gender etc., what their abilities and skills are, what they do and how they act. Some others factors are for example their creature comforts, luck, time, setting and opportunities. The aim of the article is to explain the substance of one factor that influences the success of studying at university - the principle of tacit knowledge of college students (so-called academic tacit knowledge). The paper is a study overview which is based on the content analysis of expert publications and on the authors' experience gained from solving thematically focused projects.

\section{Tacit knowledge}

Since the time when the Hungarian scientist Michael Polanyi used the term "tacit knowledge" for the first time, several years have passed but interest in this phenomenon has not passed. Now in the framework of the current project being solved we have analysed 225 publications dealing with tacit knowledge.

Most authors of publications about tacit knowledge come from the U.S.A. followed by Great Britain, Canada and Australia. In the Czech Republic matters regarding tacit knowledge are reported by Mládková (2011, 2008, 2005, 2004b, 2004a) and Matošková (2008). Some authors deal with tacit knowledge within the framework of knowledge management, for example Truneček (2004), Vymětal (Vymětal et al. 2005), Hudcová (2006) and Šícha (2002). At the Faculty of Management and Economics, Tomas Bata University in Zlín a grant project was solved during the years 2008 to 2010 which dealt with managerial tacit knowledge (Gregar et al. 2011, Anon. 2010b). A graphical illustration of the interest regarding tacit knowledge, according to the number of authors, has been done on the basis of the publications analysed and is demonstrated in Fig. 1. 
Fig. 1

Interest regarding tacit knowledge according to the number of authors in the world who deal with tacit knowledge (own elaboration on the basis of analysed expert publications, valid at 28. 3. 2013)

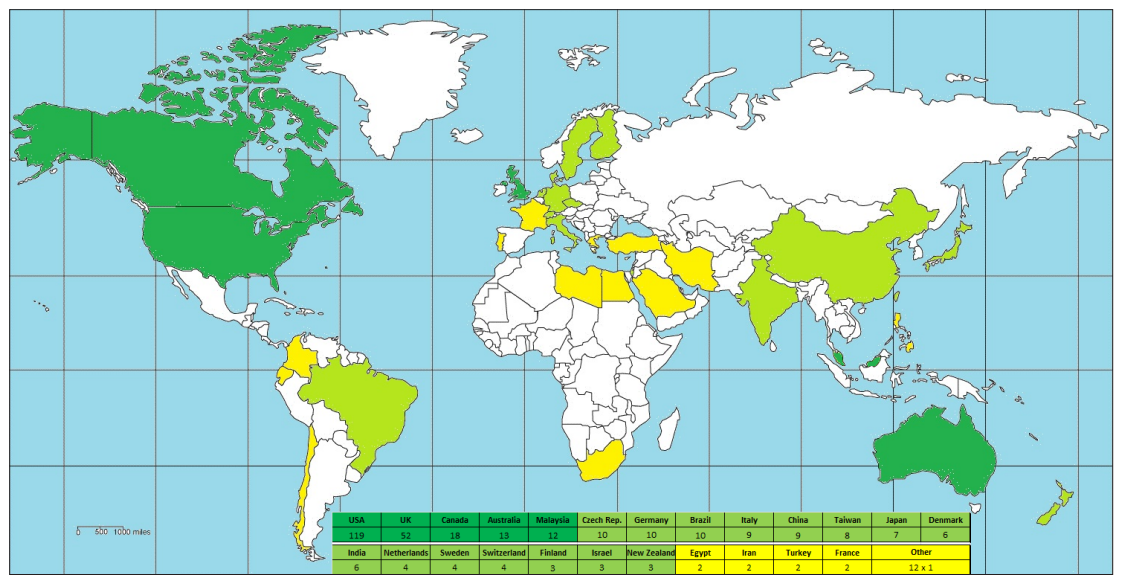

\subsection{Tacit knowledge contra explicit knowledge}

In expert literature the principle of tacit knowledge is explained in connection with explicit knowledge. McQueen (1999) characterises explicit knowledge as contextual rules "what to do in a given situation" or descriptions of a process in the form of a document or a book which can be used by others in managing their actions in situations where they do not have enough necessary experience or understanding for the situation. Johnson et al. (2002) use the term codified knowledge, instead of explicit knowledge, and they describe it as "structured data and instructions that are necessary for its elaboration" or as "knowledge reduced into a symbolic representation". Generally it can be said that explicit knowledge is knowledge which is expressed in a formal way (by letters, words, numbers or other symbols). In contrast to explicit knowledge, tacit knowledge means the knowledge in human minds (and so not written or said) but which does not mean that some tacit knowledge (or its parts) cannot have an explicit form. It is possible to use the metaphor of an iceberg (see for example Fetterhoff et al. 2011; HaldinHerrgärd 2002). Only a small part of human knowledge is above the surface, thus visible and expressed, while the rest is below the surface of human awareness and may not be documented for various reasons - e. g. impossibility, inattention, and undesirability.

In a slightly narrower concept, tacit knowledge can be defined on the basis of a content analysis of expert publications in the following way: Tacit knowledge is practical 
know-how that exists in human minds, in the background of our awareness. It is formed and modified on the basis of experience and by an influence of interactions with the setting. The term "know-how" does not mean only some technical or physical "knowing how" but also "knowing how to gain a desirable result" as well as "knowing what to do to gain such a desirable result" and "knowing when to do it" (Anon 2004). The word "practical" indicates that it is knowledge which is connected with the realisation of an action. Some authors name some concrete examples of tacit knowledge, e.g.

- knowing how to write a scientific paper (Elton 2010),

- chefs knowing how to choose and how to combine ingredients and how to act to achieve a final product which they want to cook (Mulder and Whiteley 2007),

- $\quad$ knowing how to persuade others about the value of your idea (Torff and Sternberg 1998),

- $\quad$ knowing how to negotiate successfully a business contract (Vymětal et al. 2005),

- $\quad$ knowing how to successfully lead a team (Vymětal et al. 2005),

- knowing how to make a violin (Krogh et al. 2000),

- knowing how to fix plaster (Busch a Richards 2000),

- knowing how to cycle (Mládková 2005),

- knowing how to drive (Mládková 2005),

- knowing how to operate a machine (Mládková 2005),

- $\quad$ knowing how to work with sophisticated software (Mládková 2005).

\subsection{Tacit knowledge moulding}

Cejpek (according to Švarcová 2008) and Mládková (2005, 2004b) says that if we create tacit knowledge, we make a path in our brain or a connection among neurons in several parts of our brain and the signal runs on its way. If the knowledge is not fully acquired the signal moves more slowly from one neuron to the next neuron. Frequently used connections between neurons force, ramify and bend to enable an easier transit of an impulse.

Insch et al. (2008) claim that tacit knowledge is created in our brain from information (pieces of knowledge) which can arise from our setting, motivation, opportunities or exposure to something. These pieces of knowledge are confirmed and broadened on the base of experience by verification, trial-error and by reflecting on gained lessons.

Sternberg and Wagner (1992) as well as Nestor-Baker and Hoy (2001) show that the amount of tacit knowledge grows with experience but the amount of experience is not so important as the ability to learn from experience and to use gained knowledge.

Many authors, e.g. Edwards and Schleicher (2004), Germain and Quinn (2005), Leonard and Insch (2003), Liao (2005), Nestor-Baker and Hoy (2001), Matthew and Sternberg (2009), Krishnaveni and Sujatha (2012), Senapathi (2011), Waldman (2008), Rosman, Biggs and Hoskin (2012), Sternberg et al. (2001), Fox (1997), Sternberg (1997), 
Giunipero et al. (1999), Elton (2010), say that tacit knowledge is gained mostly by way of implicit and informal learning because tacit knowledge is often not taught directly. However, according to Sternberg (1995) and some others authors, e. g. Brockmann and Anthony (2002), Fox (1997), this does mean that at least some tacit knowledge cannot be taught. For example courses on how to speak in public and how to apply for a job etc. can be taught.

\subsection{Manifestation of owning tacit knowledge}

The fact that people have tacit knowledge manifests itself for example in the following ways:

- we sometimes act spontaneously without previous thinking about it and often without being aware of why we act in that way (Gourlay 2002, Rolf according to Toom 2006),

- we sometimes are not able to explain how we do something - we are not able to express it with words, numbers or other symbols (Gourlay 2002, Rolf according to Toom 2006),

- we sometimes know what to do and what not to do in a given situation, but we are not able to explain how it happens that we know it (Peterson a Walker 2005),

- we manage some actions (we have appropriate skills) - see e.g. Peterson and Walker (2005).

Authors agree that tacit knowledge influences our actions - see e. g. Mohamed (2010), Freitas and Macedo-Soares (2001), Deed and Gomez (2010), Haldin-Herrgärd (2002), Bennett (1998), Švec (2003). According to some authors tacit knowledge influences not only actions but it also influences our attitudes, assumptions (ANON. 2004; Elton 2010) and feelings (Zhang and Han 2009).

\subsection{The Importance of tacit knowledge}

Sternberg (1997) says that tacit knowledge enables individuals to achieve their valuable goals. Similarly, Wagner (1985) mentions that to be successful in a work setting requires among others tacit knowledge. Armstrong (2001) mentions that (explicit as well as tacit) knowledge gaining and its activation assists people to succeed in their everyday efforts. Probably therefore Sternberg and Wagner (according to Fox 1997) and Colonia-Willner (1999) consider tacit knowledge gaining and using to be an important aspect of success in work.

The importance of tacit knowledge consists in the fact that tacit knowledge is necessary for successfully coping with some situations (Bennett 1998; Ambrosini and Bowman 2001; Büssing and Herbig 2003). Individuals learn on the base of experience which 
factors are the most important, how certain behaviour is understood, how people react, how events progress and so they form tacit knowledge. According to Baumard (1996) tacit knowledge plays a key role especially in understanding ambiguous situations.

Tacit knowledge also helps individuals to deal with a new situation - to adapt to it, to modify it or to fulfil some gaps in formal training (Gourlay 2002; Colonia-Willner 1999). According to Sternberg (Sternberg et al. 1993; Sternberg 1995) tacit knowledge is used also in decision-making if the setting is suitable or not and if not whether a new setting should be found or if the current setting should be modified somehow to be more suitable.

Baumard (according to Gourlay 2002), Choi (2001), Haldin-Herrgärd (2000) connect tacit knowledge with expertise. Swap et al. (2001) agree with that fact and explain that all experts go through several levels of gaining knowledge (apprentice - journeyman - master, alternatively beginner - advanced - expert). Only tacit knowledge separates masters from journeymen and journeymen from apprentices. That is because most tacit knowledge consists of recognising a situation as suitable for using a specific procedure or for action on a pattern or in recognising that a procedure is not useful in such a situation because it appeared previously to be faulty. (Eraut 2000; Leonard and Sensiper 1998). Experts have in their long-term memory extensive databases of knowledge which give them patterns of actions and so enable them to decide about the next steps without considering a whole range of possible strategies. Novices miss such knowledge. Therefore novices have a tendency to keep rules and procedures which they were taught without considering any differences in context. On the other hand real experts have enough qualifications to be able to distinguish among different contexts and to decide quickly about the next steps (Anon 2010a; Giunipero et al. 1999).

According to the findings of Bennett (1998), Brockmann and Simmonds (1997), Leonard and Sensiper (1998) also Germain and Quinn (2005) tacit knowledge can help:

- to define a problem better and to realise what is important,

- to understand the meaning of information and to create a compact unit from it,

- to judge the impacts of actions,

- to see which problem needs a radical solution and which is better to be solved diplomatically,

- to recognise small details which can be important for the success of the action.

Therefore thanks to tacit knowledge decision-making leads to a higher probability of a successful problem resolution. Additionally, Mládková (2004b, 2005) and Cejpek (according to Švarcová 2008) believe that when we have tacit knowledge then the process of decision-making is faster. 


\section{Academic tacit knowledge}

A project currently being solved at the Faculty of Management and Economics TBU in Zlín, deals with academic tacit knowledge. Academic tacit knowledge is not a new term. In other countries several publications aimed at academic tacit knowledge appeared at the end of $20^{\text {th }}$ century. Authors of expert texts about tacit knowledge include Sternberg and Wagner (Sternberg et al. 1993; Wagner 1985), Leonard and Insch (2005), Somech and Bogler (1999), Insch, Mclntyre and Dawley (2008), Edwards and Schleicher (2004). In the Czech Republic there has not been an effort to deal with the tacit knowledge of college students. An exception is the study made by Švec $(2003,2002)$ which takes notice of tacit knowledge with pedagogy students.

On the basis of the study mentioned above expert sources and literature dealing with tacit knowledge generally, academic tacit knowledge can be defined as the individual and practical knowledge of students of bachelor and master study programmes. The knowledge is connected within the college setting. It helps students to cope with situations they are exposed to and helps them to achieve their goals. Such situations are related to coping with study requirements, with learning, interactions with other students and teachers and also gaining practical experience. The knowledge, as the principle of tacit knowledge implies, is gained on the basis of experience and often without any direct help from others. Often students are not aware that they have such knowledge and that it helps them to achieve their goals.

Sternberg et al. (1993) and Insch et al. (2008) claim that academic tacit knowledge is necessary for success at college. According to Wagner (1985) the ability to form it is a mark of so-called practical intelligence. Schmidt and Hunter (1993) and Woo et al. (2004) designate it as a possible indicator of school performance which Somech and Bogler (1999) also confirm.

Examples of academic tacit knowledge are "knowing how to pass an exam" (Leonard and Insch 2005; Insch et al. 2008), academic writing (Elton 2010; Tschannen-Moran and Nestor-Baker 2004) and "knowing how to negotiate in a given setting" (TschannenMoran and Nestor-Baker 2004). We can also add skills that are presented by Price and Maier (2010) - coping with stress, time management, "knowing how to take notes", "knowing how to gain the maximum from lectures", "knowing how to manage team work", "knowing how to make a presentation", "knowing how to read expert literature". Insch et al. (2008) have even suggested a classification of academic tacit knowledge. They distinguish:

- cognitive (self-motivation and self-organisation),

- technical,

- and social. 
From the publication of O'Donovan et al. (2004) it seems that one influence on tacit knowledge forming can come from a teacher, from their way of giving tasks followed by feed-back. However, the main role belongs to the students themselves.

The owning of academic tacit knowledge as well as the ability to form the knowledge quickly and to development it manifests itself in the behaviour of students. From literature on studying it seems that a successful student:

- goes to school regularly (Insch et al. 2008; Yazedjian et al. 2008),

- goes on time (Sternberg et al. 1993; Leonard and Insch 2005),

- joins actively in the classroom (Insch et al. 2008; Leonard and Insch 2005; Somech and Bogler 1999),

- participates in group work besides direct classwork (Insch et al. 2008; Yazedjian et al. 2008; Leonard and Insch 2005),

- speaks with teachers, e. g. after lessons or in their consultation hours (Insch et al. 2008; Yazedjian et al. 2008; Sternberg et al. 1993; Leonard and Insch 2005; Somech and Bogler 1999),

- finishes their tasks on time (Leonard and Insch 2005; Sternberg et al. 1993; Leonard and Insch 2005),

- reads the recommended texts (Sternberg et al. 1993),

- makes detail notes (Sternberg et al. 1993),

- regularly goes through their notes from the lessons (Leonard and Insch 2005; Somech and Bogler 1999),

- consults with experienced students regarding expectations and requirements in subjects (Leonard and Insch 2005; Somech and Bogler 1999; Insch et al. 2008),

- decides on priorities and on actions (Leonard and Insch 2005; Tschannen-Moran and Nestor-Baker 2004),

- takes part in activities of student organisations (Leonard and Insch 2005),

- uses different organisational instruments like planners, calendars, lists of tasks, folders, dividers (Prevatt et al. 2011),

- uses an outline to identify main ideas (Prevatt et al. 2011),

- utilises their own instruments like diagrams, graphs, summaries, time axes, notes in texts, highlighting, underlining etc. (Prevatt et al. 2011),

- makes relationships which give them social support as well as professional challenges and stimulation (Tschannen-Moran and Nestor-Baker 2004; Leonard and Insch 2005) - they make and cultivate relationships with people who

$>$ have skills that they do not have themselves,

$>$ have similar interests and compatible personalities,

$>$ have power,

- focuses on a concrete area and profiles it (Tschannen-Moran and Nestor-Baker 2004), 
- asks for feed-back (Tschannen-Moran and Nestor-Baker 2004),

- communicates with administrative employees - e. g. secretaries, librarians, workers from IT department - to gain useful information (Somech and Bogler 1999).

\section{Conclusion}

Tacit knowledge belongs to factors which influence the success of individuals in their lives. Therefore it is desirable to know more about its formation, moulding, development and identification. It is confirmed by the popularity of the topic in foreign literature. Additionally, academic tacit knowledge is connected with an important period in professional preparation. The ability to form and develop such knowledge can be connected with assertion on the labour market. Information about concrete tacit knowledge related to a student role in a given academic setting can be used in managing and facilitating the adaptation of new students in a college setting, in supporting tacit knowledge formation and in the individualisation and differentiation of studies. Because of the reasons mentioned above, the research of academic tacit knowledge seems useful.

The topic academic tacit knowledge is also linked to a project currently being solved at the Faculty of Management and Economics, TBU in Zlín. Its aim is to prepare an instrument for academic tacit knowledge measurement. The instrument could be used as a complement to the standard psychological tests being used. It will be possible to use it for example with students' self-diagnostic and self-development. It may also help in the search for talented students.

\section{References}

Bennett, R. H. (1998). The Importance of Tacit Knowledge in Strategic Deliberations and Decisions. Management Decision, 36(9), 589-597.

Elton, L. (2010). Academic writing and tacit knowledge. Teaching in Higher Education, 15(2), 151-160. doi: 10.1080/13562511003619979

Gourlay, S. (2002). Tacit Knowledge, tacit knowing or behaving?

Insch, G. S., McIntyre, N., \& Dawley, D. (2008). Tacit Knowledge: A Refinement and Empirical Test of the Academic Tacit Knowledge Scale. The Journal of Psychology, 142(6), 561-79.

Leonard, N., \& Insch, G. S. (2005). Tacit Knowledge in Academia: A Proposed Model and Measurement Scale. The Journal of Psychology, 139(6), 495-512.

Mládková, L. (2004b). Management znalostí v praxi. Praha: Professional Publishing.

Mládková, L. (2005). Moderní přistupy k managementu: tacitní znalost a jak ji řídit. Nakladatelství C. H. Beck.

Nestor-Baker, N. S., \& Hoy, W. K. (2001). Tacit Knowledge of School Superintendents: Its Nature, Meaning, and Content. Educational Administration Quarterly, 37(1), 86-129.

doi: $10.1177 / 00131610121969253$ 
Prevatt, F., Huijun Li, Welles, T., Festa-Dreher, D., Yelland, S., \& Jiyoon Lee. (2011). The Academic Success Inventory for College Students: Scale Development and Practical Implications for Use with Students. Journal of College Admission, (211), 26-31.

Somech, A., \& Bogler, R. (1999). Tacit Knowledge in Academia: Its Effects on Student Learning and Achievement. Journal of Psychology, 133(6), 605.

Sternberg, R. J., Wagner, R. K., \& Okagaki, L. (1993). Practical Intelligence: The Nature and Role of Tacit Knowledge in Work and at School.

Tschannen-Moran, M., \& Nestor-Baker, N. (2004). The Tacit Knowledge of Productive Scholars in Education. Teacher College Record, 106(7), 1484-1511.

Vymětal, J., Diančiková, A., \& Váchová, M. (2005). Informační a znalostní management v praxi. Praha: LexisNexis CZ.

Wagner, R. K. (1985). Tacit knowledge in everyday intelligent behavior. Yale University, USA.

Yazedjian, A., Toews, M. L., Sevin, T., \& Purswell, K. E. (2008). "It's a Whole New World": A Qualitative Exploration of College Students' Definitions of and Strategies for College Success. Journal of College Student Development, 49(2), 141-154.

\section{Acknowledgements}

This contribution was written within the framework of the GA ČR (Czech Science Foundation) grant-maintained project: Reg. No. 407/12/0821, Creating a Czech Instrument for Measuring Academic Tacit Knowledge, and with the financial support of GA ČR.

\section{Contact:}

Ing. Jana Matošková, Ph.D. et al.

Faculty of Management and Economics

Tomas Bata University in Zlín

Mostní 5139

76001 Zlín

E-mail: matoskova@fame.utb.cz 